Food, Dairy and Home Economic Research

http:/www.journals.zu.edu.eg/journalDisplay.aspx?Journalld=1\&queryType=Master

\title{
PHYSICOCHEMICAL PROPERTIES OF GELATIN EXTRACTED FROM NILE TILAPIA (Oreochromis niloticus) AND NILE PERCH (Lates niloticus) FISH SKINS
}

\author{
Hala M.R. Badway ${ }^{*}$, Somia M. Abd El-Moniem, A.M. Soliman and M.A. Rabie \\ Food Sci. Dept., Agric. Fac., Zagazig Univ., Egypt
}

\section{Received: 26/06/2019; Accepted: 30/07/2019}

\begin{abstract}
Fish skin is a byproduct part and can be converted into value added product like gelatin. The objective of this research was to produce gelatin from two fresh-water fish skins i.e. Nile tilapia (Oreochromis niloticus) and Nile perch (Lates niloticus) and determine the physicochemical characteristics of the obtained gelatin. The physicochemical properties, free amino acids, protein content, $\mathrm{pH}$, viscosity, colour, melting point, clarity, water holing capacity (WHC) and fat binding capacity (FBC), were studied and compared to the commercial bovine gelatin. Nile perch gelatin presented $(87.24 \%)$ protein content which was resembles to bovine gelatin $(88.18 \%)$. The viscosity $(6.02 \mathrm{cP})$ of Nile tilapia extracted gelatin was also comparable to the bovine gelatin $(6.77 \mathrm{cp})$. Results showed that the lightness of Nile tilapia gelatin (37.07) was greater than that of bovine gelatin (31.75). Regarding to the WHC, of Nile perch gelatin was higher by 3 -fold $(687.97 \%)$ than bovine gelatin (225.17\%). While the Nile tilapia presented 1.4-fold (637.18\%) higher than that found in bovine gelatin. Based on obtained results, it could be recomended that fish gelatin could be considered an excellent alternative to mammalian gelatin because of its functional properties similarity with commercial bovine gelatin.
\end{abstract}

Key words: Fish gelatin, Fresh water fish, Extraction and characterization, Alternative resource of gelatin.

\section{INTRODUCTION}

Annually, more than 100 million tons of fish are being harvested worldwide. The waste from fish processing is as large as $70-85 \%$ of the catch and as much as $30 \%$ of waste is in the form of high-collagen bones and skins (Shahidi, 1994). Egypt has the greatest number of fish farms in Africa with 4 out of every 5 fish farms in Africa located in Egypt (Shaheen, 2013). Fish production in Egypt contributes about $70.5 \%$ of the total fish production on the African continent Sadek (2011), Kleih et al. (2013) and Samy-Kamal (2015). This waste is an outstanding raw material for the preparing of elevated protein foods and gelatin in particular. Converting waste into value-added products to generate additional revenue has economic and waste management benefits for the fisheries sector (Choi and Regenstein, 2000). With a

\footnotetext{
*Corresponding author: Tel. : +201111366151

E-mail address: hala.badwey@Zu.edu.eg
}

constantly rising worldwide demand for gelatin, many prospective sources to tackle this increasing need are being sought. Global gelatin manufacturing reached approximately 375000 400000 tons a year in 2016 (FAO, 2016). Most gelatins are from pork skins, bones of pork and bovine animals, or hides of divided cattle. Most of these are obtained from pig, beef, bone and other sources, contributing 46\%, 29.4\%, 23.1\% and $1.5 \%$, respectively (NHPID, 2013). Due to the fact that half of the manufacturing is produced by porcine, the Halal or Kosher industry is a major concern. Also, the incidence of spongiform encephalopathy (BSE) or "crazy cow's illness" and religious reasons are necessary for bovine gelatin. Therefore, the production of fish gelatin is growing as an alternative for the mammalian counterpart (Gudmundsson, 2002).

A number of researches have examined the characteristics of fish-skin gelatin that differ 
from mammalian gelatin and differ between fish species (Karim and Bhat, 2009). Gelatin qualities are dependent upon their physicochemical characteristics which are heavily affected by their species or tissue and the severity of the manufacturing process as well. The functional characteristics of gelatin such as gel strength, viscosity, adjustment and melting point rely on composition their molecular weight and amino acid compounds (Johnston-Banks, 1990). Fish gelatin have low gelling and melting temperatures and also lower gel strength compared to mammalian gelatin due to its low content of amino acids proline and hydroxyproline (Norland, 1990).

The aims of the research was to extract gelatin and to assess the physicochemical properties and comparison between the commercial bovine gelatin and two fresh water Nile tilapia (Oreochromis niloticus) and Nile perch (Lates niloticus) skins.

\section{MATERIALS AND METHODS}

Freshly generated fish wastes skins of two cultured fresh water fish, Nile tilapia (Oreochromis niloticus) and Nile perch (Lates niloticus) were purchased from Alobour city market, Egypt and were transported submerged in equal volume of ice to the laboratory and stored at $-20^{\circ} \mathrm{C}$ until further use. Halal Bovine gelatin was purchased from local market in Zagazig, Egypt. Chemicals were obtained from Elgomhoria Company, Zagazig.

\section{Extraction of Gelatin from Fish Skin}

The skin of fish was taken out from the freezer and allowed to melt, skin was descaled with hand knife and weighed. Gelatin was extracted according the method of ( Ockerman and Hansen ,2000). After descaling, the skin was washed using tap water for 1 hour and then soaked at room temperature $\left(25 \pm 1^{\circ} \mathrm{C}\right)$ in $0.4 \%$ $(W / V) \mathrm{NaOH}$ aqueous 1:8 $(W / V)$ ratio for $4 \mathrm{hr}$ $\left(25 \pm 1^{\circ} \mathrm{C}\right)$. The skin was washed again with running tap water for 1 hour and subsequently soaked with $0.4 \%(V / V)$ aqueous $\mathrm{HCl}$ solution for another $4 \mathrm{hr}$ in the same ratio at room temperature .With running tap water, the skin washed again to $\mathrm{pH}$ neutral $(\mathrm{pH} 7)$. At last, skin/water proportion 1:2 $(W / V)$ was obtained with distilled water for $1.5 \mathrm{hr}$ at $70^{\circ} \mathrm{C}$. Two layers of cheese cloth were used for filtered and the sample was evaporated at $70^{\circ} \mathrm{C}$ to remove $70 \%$ of water. The filtrate has been dried in a hot-air oven for $18 \mathrm{hr}$ at $50^{\circ} \mathrm{C}$. The resulting gelatin was stored in a desiccator for further use.

\section{Determination of Yield}

Yield of gelatin extracts produced from each fish sample was determined according to (AOAC, 2000) using the following equation:

$$
\text { Yield }(\%)=\frac{\text { Weight of gelatin }}{\text { Weight of skin }} \times 100
$$

\section{Detremination of Chemical Properties and $\mathrm{pH}$ of Gelatin}

Chemical composition (moisture, ash, protein and fat content) was carried out according to (AOAC, 2012). The $\mathrm{pH}$ values of gelatin from fish skin solutions were measured as described by (Vareltzis et al., 1997) using 1\% (W/V) solution of gelatin prepared in distilled water at $60^{\circ} \mathrm{C}$, cooled to room temperature and the $\mathrm{pH}$ was measured using $\mathrm{pH}$ meter (model 646 Digital, USA) in Food Safety Laboratory, Faculty of Agriculture, Zagazig University, Egypt.

\section{Detremination of Physical Properties of Gelatin}

\section{Colour measurmant}

Colour of gelatin gels were measured based on the method described by Jamilah et al. (2011) using a Hunter Lab (colour Flex EZ Spectrophotometer, USA) in Food Safety Laboratory, Faculty of Agriculture, Zagazig University. Samples were read three times and reported as $\mathrm{L}^{*}, \mathrm{a}^{*}$ and $\mathrm{b}^{*}$ parameters indicating lightness, redness/greenness and yellowness/ blueness, respectively.

\section{Viscosity}

Viscosity was determined using Brookfield Digital Viscometer (Model DV-1+ viscometer, LV Version 4,1, USA) in Food Safety Laboratory, Faculty of Agriculture, Zagazig University equipped with a No.1 spindle at $30 \pm 0.5^{\circ} \mathrm{C}$ according to Cho et al. (2006).

\section{Water holding capacity and fat binding capacity}

Water holding capacity (WHC) and fat binding capacity (FBC) were measured as the method described by Cho et al. (2004). 


\section{Clarity}

Gelatin (about $7.50 \mathrm{~g} \pm 0.01$ ) was weighed into a $150 \mathrm{ml}$ bottle and $105 \mathrm{ml}( \pm 0.2)$ water was added. The absorbance at $620 \mathrm{~nm}$ was measured at room temperature. Against deionized water (ISO, 1999) by spectrophotometer model (Jenway 6705, UK), in Food Safety Laboratory, Faculty of Agriculture, Zagazig University.

\section{Foaming properties}

Foam formation ability and foam stability of gelatin were determined by the procedure of (Cho et al., 2004).

\section{Melting point}

Melting point was determined according to the method described by Wainewright (1977).

\section{Setting point and setting time}

Setting point and setting time of gelatin were determined by the method of Muyonga et al. (2004).

\section{Determination of Amino Acid Composition}

Amino acids were determined according to the methods described by Moore (1958). Sample of $20-25 \mathrm{mg}$ was placed in glass hydrolysis tube containing $10 \mathrm{ml}$ of $6 \mathrm{~N} \mathrm{HCL}$ with $0.1 \%$ mercaptoethanol. The tube was sealed and heated in an oven at $110^{\circ} \mathrm{C}$ for $24 \mathrm{hr}$. The hydrolyzed sample was then cooled to room temperature and filtered through Whatman No 1 filter paper. The tube and precipitate on the paper was washed with distilled water and the filtrates were then completed to $25 \mathrm{ml}$ in a volumetric flask. Five $\mathrm{ml}$ of the filtrate were transferred to a $25 \mathrm{ml}$ beaker and placed under vacuum in a desiccators over potassium hydroxide. The resulted dried residue was dissolved in one $\mathrm{ml}$ of sodium citrate buffer of $\mathrm{pH} 2.2$ and stored at $4^{\circ} \mathrm{C}$ until analyzed by Beckman Amino Acid Analyzer Model 119.

\section{RESULTS AND DISCUSSION}

The yield of the fish skin gelatin obtained from the Nile tilapia and Nile perch were $3.80 \%$ and $8.65 \%$, respectively. Gómez-Guillén and Montero (2001) reported that the different marine species has different structural and physical properties of gelatin which affects on the yield. While, a study by Jamilah and
Harvinder (2002) and Tabarestani et al. (2010) suggested that the wide diversity among the fish species present intrinsic differences in the collagen molecules present in their skin. Moreover, the lower susceptibility of the collagenous material from fish skin to degradation is due to the lower content in intraand inter-chain non-reducible crosslinks. Karim and Bhat (2009) reported that the yield and quality of gelatin are influenced by the species and age of the fish, extraction process and pretreatment temperature.

\section{Chemical Composition}

Table 1 shows the chemical composition of extracted gelatin from two different fresh water fish skins and comparison with bovine gelatin. The protein content of the starting raw material represents the maximum possible yield of gelatin that can be expected. Protein content of Nile tilapia was $83.69 \%$ and Nile perch $87.24 \%$. All investigated samples were significantly lower in protein content than that of commercial gelatin $88.18 \%$. Ash content of gelatin from Nile tilapia was $0.26 \%$ and Nile perch $0.15 \%$ and they were also lower than that of commercial gelatin $0.82 \%$. The high ash content in bovine gelatin was due to high quantity of minerals in the skins. Benjakul et al. (2009) stated that high quality gelatin should contain no more than $0.5 \%$ ash. Moisture content showed that gelatin from Nile tilapia $8.26 \%$ and Nile perch $8.13 \%$. These values were lower than that found in commercial gelatin $8.52 \%$. Lipid content in Nile perch showed the highest value by $1.24 \%$ while, the Nile tilapia and commercial gelatin had showed low content of lipid valued $0.55 \%$ and $0.21 \%$, respectively.

Balti et al. (2011) also reported that the bovine gelatin contained $90.22 \%$ protein, $8.52 \%$ moisture, $0.21 \%$ fat and $0.29 \%$ ash.

The $\mathrm{pH}$ of the extracted fish gelatin is given in Table 1. Nile perch gelatin shows significantly higher value (4.07) than that of Nile tilapia (3.99). The values of $\mathrm{pH}$ for gelatin samples were compared with bovine gelatin (6.24). The difference in values may be due to the pretreatment method employed during the extraction process which involves both alkali and acid treatments. Functional properties of gelatin viz., gel strength and melting point are 
Table 1. Chemical composition and pH of bovine, Nile tilapia and Nile perch gelatins

\begin{tabular}{lccccc}
\hline Gelatin type & $\begin{array}{c}\text { Moisture } \\
\mathbf{( \% )}\end{array}$ & $\begin{array}{c}\text { Lipid } \\
\mathbf{( \% )}\end{array}$ & $\begin{array}{c}\text { Protein } \\
\mathbf{( \% )}\end{array}$ & $\begin{array}{c}\text { ASH } \\
\mathbf{( \% )}\end{array}$ & pH \\
\hline Bovine & $8.52 \pm 0.08$ & $0.21 \pm 0.01$ & $88.18 \pm 0.17$ & $0.82 \pm 0.01$ & $6.24 \pm 0.02$ \\
Nile tilapia & $8.26 \pm 0.02$ & $0.55 \pm 0.02$ & $83.69 \pm 0.09$ & $0.26 \pm 0.01$ & $3.99 \pm 0.02$ \\
Nile perch & $8.13 \pm 0.01$ & $1.24 \pm 0.08$ & $87.24 \pm 0.14$ & $0.15 \pm 0.04$ & $4.07 \pm 0.01$ \\
\hline
\end{tabular}

* Means and standard deviation analyzed in triplicate.

dependent on $\mathrm{pH}$. (Choi and Regenstein, 2000) observed that the gel strength of the fish and pork gelatin decreased markedly below $\mathrm{pH} 4$ and slightly above $\mathrm{pH} 8$. For the melting point also similar dependencies were observed in relation to $\mathrm{pH}$.

\section{Colour Parameters of Gelatin}

The gelatin obtained from the different species of fresh water fish is given in Table 2. The $\mathrm{L}^{*}$ value of gelatin obtained from Nile tilapia skin was 37.07 and Nile perch 35.11 which were higher compared to the commercial gelatin 31.35 . However, $a^{*}$ value of Nile tilapia gelatin was -1.25 and Nile perch was -0.36 and $\mathrm{b}^{*}$ value of Nile tilapia gelatin was 7.97 and Nile perch 8.31. The*a and $b^{*}$ of commercial gelatin were higher than those of fresh water fish gelatin recording 1.56 and 9.31, respectively. Ockerman and Hansen (1999) noted that the appearances of gelatin from striped snakehead visually are close to that of commercial one whereas Nile perch and Nile tilapia gelatin are similar to pig gelatin. The colour of the gelatin depends on the raw material. However, it does not influence other functional properties. The lighter colour of gelatin may have more commercial satisfaction.

\section{Viscosity}

Viscosity is the second most important property of gelatin. Table 3 shows the viscosity of the two fish species of fresh water fish compared to commercial bovine gelatin. The viscosity obtained from Nile tilapia and Nile perch were $6.02 \mathrm{cP}$ and $5.96 \mathrm{cP}$, respectively These values were significantly lower than that of commercial gelatin $6.77 \mathrm{cP}$. (Schrieber and
Gareis, 2007) noted that the viscosity increases with increasing gelling temperature, melting temperature, melting point and gel strength. The results here indicated that high viscosity gelatin can be prepared from Nile tilapia and Nile perch.

\section{Clarity (\%)}

Table 3 shows the different clarity (\%)of the two fish species of fresh water fish compared to commercial bovine gelatin .Bovine gelatin exhibited better clarity (1.814) than gelatin obtained from Nile perch (1.490) and Nile tilapia (1.074) and there are significant differences were observed between gelatin clarity of Nile tilapia, and Nile perch and bovine gelatin. Montero et al. (2002) reported that high temperature extraction can result in higher molecular weight aggregates which will increase the turbidity of the gel and affect the clarity. Clarity is important in commercial applications and this property is frequently assessed for determining the quality of gels.

\section{Water holding capacity (WHC) and fat binding capacity (FBC)}

Water holding capacity of Nile tilapia $(637.18 \%)$ and Nile perch (687.97\%) and bovine gelatin $(225.17 \%)$ is given in Table 4 . Waterholding capacity is affected by the amount of hydrophilic amino acids like proline. In the present study the highest water holding capacity (687.97\%) was observed for Nile perch gelatin, this may be due to significantly higher percentage of proline $(33.6 \%)$ in Nile perch gelatin as compared to Nile tilapia (15.1\%) and bovine gelatin (12.66\%). 
Table 2. Colour as measured by Hunter Lab of gelatin from bovine, Nile tilapia and Nile perch gelatins

\begin{tabular}{lccc}
\hline Gelatin type & $\mathbf{L}^{*}$ & $\mathbf{a}^{*}$ & $\mathbf{b}^{*}$ \\
\hline Bovine & $31.75 \pm 0.10$ & $1.56 \pm 0.02$ & $9.31 \pm 0.14$ \\
Nile tilapia & $37.07 \pm 0.34$ & $-1.25 \pm 0.06$ & $7.79 \pm 0.02$ \\
Nile perch & $35.11 \pm 0.06$ & $-0.36 \pm 0.01$ & $8.31 \pm 0.02$ \\
\hline
\end{tabular}

* Results are means. $\mathrm{L}^{*}=$ the lightness $\mathrm{a}^{*}=$ Redness $\mathrm{b}^{*}=$ Yellowness * Means and standard deviation analyzed in triplicate.

Table 3. Viscosity and clarity of bovine, Nile tilapia and Nile perch gelatins

\begin{tabular}{lcc}
\hline Gelatin type & Viscosity(cp) & Clarity(\%) \\
\hline Bovine & $6.77 \pm 0.02$ & $1.814 \pm 0.17$ \\
Nile tilapia & $6.02 \pm 0.25$ & $1.074 \pm 0.03$ \\
Nile perch & $5.96 \pm 0.01$ & $1.490 \pm 0.01$ \\
\hline
\end{tabular}

* Means and standard deviation analyzed in triplicate.

Fat binding capacity, it can be observed in Table 4 that Nile tilapia gelatin exhibited the highest value $(470.34 \%)$ and was significantly differe from both Nile perch $(363.02 \%)$ and bovine gelatin $(342.12 \%)$. Fat binding capacity depends on the degree of exposure of the hydrophobic residues inside the gelatin. The high value of fat binding capacity of Nile tilapia skin $(470.34 \%)$ gelatin may be due to the highest percentage of hydrophobic residue tyrosine (Cho et al., 2004). Water-holding and fat-binding capacities are functional properties that are closely related to texture by the interaction between water, oil and other components (Cho et al., 2004).

\section{Foaming Formation and Foam Stability}

Foam formation is an important functional property of gelatin for commonly used foods such as marshmallows. The foaming formation (ability FFA) and foam stability (FS) of Nile tilapia, Nile perch and bovine gelatin are given in Table 4. Results showed that there is no significant differences between both fish gelatin Nile tilapia $(2.45 \%)$ and Nile perch in respect to foam ability (the ratio of foam volume/liquid volume). Foam ability of both gelatins of fish species Nile tilapia $(2.27 \%)$ and Nile perch $(2.45 \%)$, under study showed low significant differences compared with bovine gelatin $(2.75 \%)$. Foam stability (the ratio of the initial volume of foam/final volume after $30 \mathrm{~min}$ ) was significantly higher for Nile tilapia (2.04\%) than for Nile perch $(1.90 \%)$ and bovine gelatin $(1.70 \%)$. The hydrophobic areas on the peptide chain are responsible for giving gelatin its emulsifying and foaming properties (Galazka $\boldsymbol{e t}$ al., 1999; Cole, 2000). The reduced foam formation and stability may be due to aggregation of proteins which interfere with interactions between the protein and water needed for foam formation (Cho et al., 2004).

\section{Melting Temperature}

Table 5 shows the melting point of gelatin obtained from Nile tilapia $\left(28.47^{\circ} \mathrm{C}\right)$. It was significantly higher than that of Nile perch $\left(21.4^{\circ} \mathrm{C}\right)$. The Nile perch was significantly lower in melting point than that of commercial gelatin $\left(29.87^{\circ} \mathrm{C}\right)$ but Nile tilipa was near similar with bovine gelatin. (Gudmundsson, 2002) observed that gelatin with high melting temperature formed stronger gels. 
Table 4. Water holding capacity and fat binding capacity and foam stability and foam ability of bovine and Nile tilapia and Nile perch gelatins

\begin{tabular}{lcccc}
\hline Gelatin type & $\begin{array}{c}\text { Water holding capacity } \\
\mathbf{( \% )}\end{array}$ & $\begin{array}{c}\text { Fat binding capacity } \\
\mathbf{( \% )}\end{array}$ & $\begin{array}{c}\text { Foam stability } \\
\mathbf{( \% )}\end{array}$ & $\begin{array}{c}\text { Foam ability } \\
\mathbf{( \% )}\end{array}$ \\
\hline Bovine & $225.17 \pm 0.05$ & $342.12 \pm 1.13$ & $1.70 \pm 0.21$ & $2.75 \pm 0.25$ \\
Nile tilapia & $637.18 \pm 3.93$ & $470.43 \pm 2.54$ & $2.04 \pm 0.08$ & $2.45 \pm 0.01$ \\
Nile perch & $687.97 \pm 4.50$ & $363.32 \pm 1.96$ & $1.90 \pm 0.16$ & $2.27 \pm 0.02$ \\
\hline
\end{tabular}

* Means and standard deviation analyzed in triplicate.

Table 5. Melting point $\left({ }^{\circ} \mathrm{C}\right)$ and setting temperature $\left({ }^{\circ} \mathrm{C}\right)$ and setting time (sec) of bovine and Nile tilapia and Nile perch gelatin

\begin{tabular}{lccc}
\hline Gelatin type & Melting point $\left({ }^{\circ} \mathbf{C}\right)$ & Setting temperature $\left({ }^{\circ} \mathbf{C}\right)$ & Setting time (sec.) \\
\hline Bovine & $29.87 \pm 0.05$ & $22.94 \pm 0.03$ & $63.96 \pm 1.02$ \\
Nile tilipa & $28.47 \pm 0.05$ & $17.12 \pm 0.10$ & $403.19 \pm 3.74$ \\
Nile perch & $21.40 \pm 0.01$ & $19.90 \pm 0.15$ & $406.90 \pm 4.47$ \\
\hline
\end{tabular}

* Means and standard deviation analyzed in triplicate.

\section{Setting temperature and setting time}

Results of setting temperature in Table 5 indicate that bovine gelatin exhibited significantly higher setting temperature $\left(22.94^{\circ} \mathrm{C}\right)$ than Nile tilapia gelatin $\left(17.12^{\circ} \mathrm{C}\right)$ and Nile perch skin gelatin $\left(19.90{ }^{\circ} \mathrm{C}\right)$. The gel setting time was significantly faster in bovine gelatin (63.96 second) compared to Nile tilapia (403.19 second) and Nile perch skin gelatin (406.90 second) with no significant differences between them. Setting gel temperature denotes the gelling process which involves the transition from random coil to triple helical structure of gelatin. Setting temperature of gelatin has also been found to correlate with the amino acid content which is $24 \%$ for bovine and $16-18 \%$ for most fish. (Leuenberger, 1991) suggested that gelling and melting temperatures are also influenced by the change in ionic strength. This suggests that the junction zones and the gel network may be stabilized by both hydrogen bonds and electrostatic bonding (Haug et al., 2004).

\section{Amino Acid Composition}

The amino acid composition of the gelatin obtained from Nile tilapia and Nile perch is given in Table 6. Nile perch skin gelatin contained significant quantities of proline and alanine acids which constitute $33.6 \%$ and
$13.4 \%$, respectively but Nile tilapia skin gelatin contained low quantities of proline and alanine which constitute $15.1 \%$ and $2.7 \%$, respectively. High content of amino acids improves the rheological properties of gelatin as it is involved in the formation of triple helical regions that immobilize water (Christopher, 1993). (Lehninger et al., 1993) suggested the stability of the collagens and gelatin is also proportional to the glycine content apart from the total amino acid content. The amino acid compositions play a main role in the physical properties of gelatin.

\section{Conclusion}

The results showed that the gelatin returns of Nile tilapia (Oreochromis niloticus) and Nile perch (Lates niloticus) skin were comparatively better compared to that of many other fish species. Nile perch skin gelatin had higher amino acid content, foam ability, higher setting point and WHC than Nile tilapia skin gelatin and was similar to the gelatin derived from mammalian sources. Moreover, gelatin from the skin of Nile tilapia and Nile perch exhibited high viscosity values. In this research Nile tilapia and Nile perch are more comparable to bovine gelatin otherwise the gelling and melting temperatures and other functional characteristics noted for gelatin from their skin. 
Table 6. Amino acid composition of gelatin from bovine, Nile tilapia and Nile perch

\begin{tabular}{|c|c|c|c|}
\hline$\overline{\text { Amino acid }}$ & Nile tilapia(\%) & Nile $\operatorname{perch}(\%)$ & Bovine(\%) \\
\hline Leucine & $2.6 \pm 0.02$ & $0.3 \pm 0.09$ & $1.09 \pm 0.01$ \\
\hline Isoleucine & $0.9 \pm 0.09$ & $2.3 \pm 0.01$ & $1.01 \pm 0.02$ \\
\hline Threonine & $4.6 \pm 0.04$ & $2.0 \pm 0.01$ & $0.82 \pm 0.08$ \\
\hline Valine & 0 & 0 & $2.07 \pm 0.01$ \\
\hline Methionine & $6.3 \pm 0.01$ & $0.8 \pm 0.05$ & $0.22 \pm 0.01$ \\
\hline phenylalanine & 0 & $1.4 \pm 0.07$ & $1.60 \pm 0.03$ \\
\hline Lysine & 0 & $5.8 \pm 0.01$ & $4.86 \pm 0.12$ \\
\hline Histidine & $0.7 \pm 0.03$ & $0.9 \pm 0.02$ & ND \\
\hline Arginine & 0 & $5.3 \pm 0.04$ & $5.09 \pm 0.09$ \\
\hline Aspartic acid & $9.8 \pm 0.28$ & $1.3 \pm 0.07$ & $3.29 \pm 0.04$ \\
\hline Serine & $4.4 \pm 0.04$ & $2.5 \pm 0.04$ & $2.93 \pm 0.09$ \\
\hline Glutamic acid & $1.8 \pm 0.04$ & $10.5 \pm 0.11$ & $5.43 \pm 0.07$ \\
\hline Glycine & $8.1 \pm 0.01$ & $11.9 \pm 0.09$ & $37.05 \pm 0.03$ \\
\hline Alanine & $2.7 \pm 0.01$ & $13.4 \pm 0.42$ & $8.41 \pm 0.05$ \\
\hline Proline & $15,1 \pm 0.07$ & $33.6 \pm 0.11$ & $12.66 \pm 0.06$ \\
\hline Ammonia & 0 & $1.5 \pm 0.01$ & ND \\
\hline Cysteine & $2.5 \pm 0.02$ & $4.5 \pm 0.04$ & $0.47 \pm 0.11$ \\
\hline Tyrosine & $40.4 \pm 0.12$ & $2.1 \pm 0.02$ & $1.16 \pm 0.02$ \\
\hline Total & 100 & 100 & 88.16 \\
\hline
\end{tabular}

* Means and standard deviation analyzed in triplicate. / *Bovine gelatin benefit to Amiza et al. (2015)

\section{REFERENCES}

Amiza, S.F., P.K. Hong, K.L. Ng, W.M. Wan Aida and A.S. Babji (2015). Physicochemical properties of gelatins extracted from skins of different freshwater fish species. International Food Res. J., 17: 809-816.

AOAC (2000). Official Methods of Analysis. $15^{\text {th }}$ Ed. Virginia: Assoc. Official Anal. Chem., Inc.

AOAC (2012). Official Methods of Analysis of AOAC. Int. $19^{\text {th }}$ Ed., published by AOAC Int. Maryland 20877-2417,USA.
Balti, R., M. Jridi, A. Sila, N. Souissi, N. Nedjar-Arroume, D. Guillochon and M. Nasri (2011). Extraction and functional properties of gelatin from the skin of cuttlefish (Sepia officinalis) using smooth hound crude acid protease-aided process. Food Hydrocolloids 25(5): 943-950.

Benjakul, S., K. Oungbho, W. Visessanguan, Y. Thiansilakul and S. Roytrakul (2009). Characteristic of gelatin from the skins of bigeye snapper, Priacanthus tayenus and Priachanthus macracantus. Food Chem., 116: 445-451. 
Cho, S.H., M.L. Jahncke, K.B. Chin and J.B. Eun (2006). The effect of processing conditions on the properties of gelatin from skate (Raja kenojei) skins. Food Hydrocoll, 20: 810-816.

Cho, S.M., K.S. Kwak, D.C. Park, Y.S. Gu, C.L. Ji, D.H. Jang, Y.B. Lee and S.B. Kim (2004). Processing optimization and functional properties of gelatin from shark (Lsurus oxyrinchus) cartilage. Food Hydrocoll, 18 : 573-579.

Choi S.S. and J.M. Regenstein (2000). Physichochemical and sensory characteristics of fish gelatin. J. Food Sci., 65: 194-199.

Christopher, B.H. (1993). Gelatin-relating structure and chemistry to functionality. In Food Hydrocolloids Structures, Properties and Functions (N. Katsuyoshi and D. Etsushiro, eds.) Plenum Press, New York. NY, 347-354.

Cole, C.G.B. (2000). Gelatin in F. J. Francis (Ed.), Encyclopedia of Food Science and Technology ( $2^{\text {nd }}$ Ed.). New York: John Wiley and Sons, 4 Vols-JJD., 1188-1188

FAO (2016). Fishery and aquaculture statistics. Food and Agriculture Organization of the United Nations.

Galazka, V.B., E. Dickinson and D.A. Ledward (1999). Emulsifying behavior of globulin (Vicia faba) in mixtures with sulphated polysaccharides: Comparison of thermal and high-pressure treatments. Food Hydrocoll, 13: 425-435.

Gomez-Guillen, M.C. and P. Montero (2001). Extraction of gelatin from megrim (Lepidorhombus boscii) with several organic acids. J. Food Sci., 66 (2): 213-216

Gudmundsson, M. (2002). Rheological properties of fish gelatin. J. Food Sci., 67: 2172-2176.

Haug, I.J., K.I. Draget and O. Smidsrød (2004). Physical and rheological properties of fish gelatin compared to mammalian gelatin. Food Hydrocoll, 18 : 203-213.

ISO (1999). International Organization 7027 for Standardization, Wate QualityDetermination of Turbidity.
Jamilah, B. and K.G. Harvinder (2002). Properties of gelatins from skins of fishblack tilapia (Oreochromis mossambicus) and red tilapia (Oreochromis nilotica). Food Chem., 77: 81-84.

Jamilah, B., K.W. Tan, M.R.U. Hartini, and A. Azizah (2011). Gelatins from three cultured freshwater fish skins obtained by liming process. Food Hydrocoll, 25: 12561260 .

Johnston-Banks, F.A. (1990). Gelatin. In Harris, P. (Eds.). Food Gel, New York: Elsevier Appl. Sci., 233-289.

Karim, A.A. and R. Bhat (2009). Fish gelatin: properties, challenges an prospects as an alternative to mammalian gelatins. Food Hydrocoll, 23(3): 563-576.

Kleih, U., J. Linton, A. Marr, M. Mactaggart, D. Naziri and J.E. Orchard (2013). Financial services for small and medium-scale aquaculture and fisheries producers. Mar. Policy, 37: 106- 114

Lehninger, A.L., D.L. Nelson and M.M. Cox (1993). Three Dimensional Structures of Proteins. In Principles of Biochemistry, $2^{\text {nd }}$ Ed., Worth Publishers Inc., New York, NY, 160-197.

Leuenberger, B.H. (1991). Investigation of viscosity and gelation properties of different mammalian and fish marine sources. Food Hydrocoll, 14: 191-195.

Montero, P., M.D. Fernandez-Dlaz and M.C. Gomez-Guillen (2002). Characterization of gelatin gels by high pressure. Food Hydrocoll, 16: 197-205

Moore, S., (1958). Automatic recording apparat use in the chromatography of amino acid. Anal. Chem., $39:$ 119-121.

Muyonga, J.H., C.G.B. Cole and K.G. Doudu (2004). Extraction and physico-chemical characterization of Nile perch (Lates niloticus) skin and bone gelatin. Food Hydrocoll, 18: 581-592.

NHPID (2013). Natural Health Products Ingredients Database: Hydrolyzed Collagen. Government of Canada, Health Canada, Health Products and Food Branch, Natural 
Health Products Directorate. 12 June 2013.

Norland, R.E. (1990). Fish gelatin In Voight, M. N. and Botta, J. K. Advances in Fisheries Technology and Biotechnology for Increased Profitability, Lancaster: Technomic Publishing Co., 325-333.

Ockerman, H.W. and C.L. Hansen (1999). Glueand Gelatin. In. Animal Byproduct Processing. England: Ellis Horwood Ltd.

Ockerman, H.W. and C.L. Hansen (2000). Animal By-product Processing and Utilization, Technomic Publishing, Worth Publishers Inc., New York, NY, 160-197.

Sadek (2011). An overview on desert aquaculture in Egypt. In: Aquaculture in Desert and Arid Lands: Developmental Constraints and Opportunities. FAO technical workshop. Rome, Italy: FAO, 6-8.

Samy-Kamal, M. (2015). Status of fisheries in Egypt: Reflections on past trends and management challenges. Rev. Fish Biol. Fisher., 25 (4): 631-649

Schrieber, R. and H. Gareis (2007). Gelatin Handbook. Theory and Industrial Practice. P. 375. Weinheim:Wiley-VCH Verlag $\mathrm{GmbH}$ and Co.
Shaheen (2013). A. An industry assessment of tilapia farming in Egypt. African Union Inter-African Bureau for Animal Resources (AU-IBAR)http://www.tilapia-farming. com/ docs/global/ Egypt/tilapia_farming_egypt.pdf.

Shahidi, F. (1994). Proteins From Seafood Processing Discards. In Shahidi, F., Sikorski, Z.and Sun Pan, B. Seafood Proteins, New York: Chapman and Hall, 171-193.

Tabarestani, H.S., Y. Maghsoudlou, A. Motamedzadegan and A.R. Sadeghi Mahoonak (2010). Optimization of physico-chemical properties of gelatin extracted from fish skin of rainbow trout (Onchorhynchus mykiss). Bioresource Technol., 101: 6207- 6214.

Vareltzis, K., D. Koufidis, E. Gavrülidou, E. Papavergou and S. Vasiliadou (1997). Effectiveness of a natural rosemary (Rosmarinus officinalis) extract on the stability of filleted and minced fish during frozen storage. Z. Lebensm. Unters Forsch A., 205: 93-96.

Wainewright, F.W. (1977). Physical Test for Gelatin and Gel Products. In A. G. Ward, and Courts. (Eds.), The Science and Technology of Gelatins. London: Academic Press Inc., $507-531$.

\section{الخصـائص الفيزوكيمائيــة للجيلاتين المستخلص من جلـود ســكك البلطى وســك قشــر البياض \\ هاله محمد راشد بدوي - سومية محمد عبدالمنعم - عبدالرحمن محمد سليمان - محمد عبدالحميا ربيع قسم علوم الأغذية ـ كلية الزر اعة ـ جامعة الزقازيق ـ مصر \\ تعتبر جلود الأسماك جزء من المخلفات و التى يمكن تحويلها إلى منتجات ذات قيمة إضافية مثل الجيلاتين، وقد أجريت

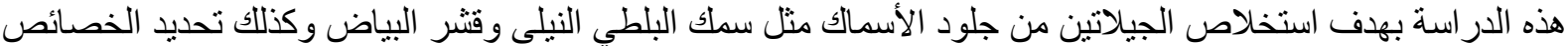

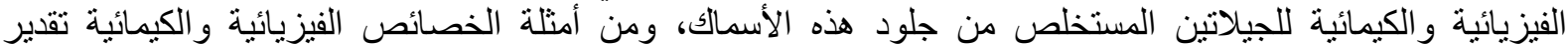

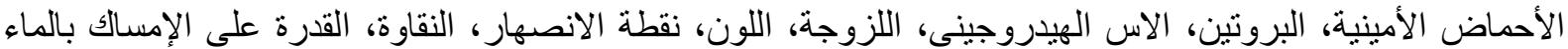

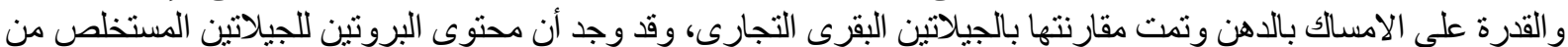

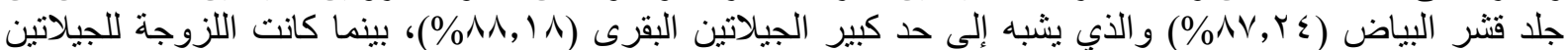

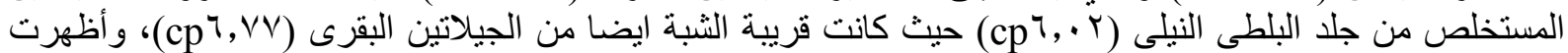

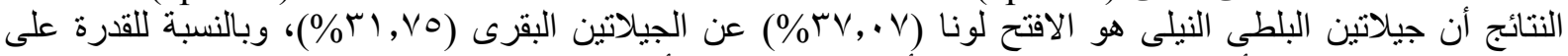

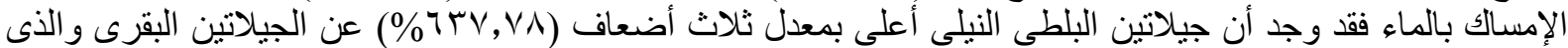

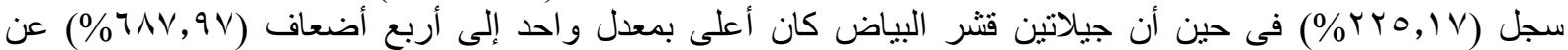

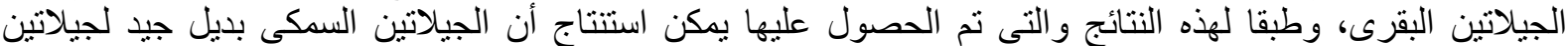 الثدييات بسبب تثابة خصائصة الوظيفية مع الجيلاتين البقرى التجارى.}

أستاذ الصناعات الغذائية ـ كلية السياحة و الفنادق ـ جامعة قناة السويس. أستاذ مساعد الصناعات الغذائية ـ كلية الزر اعة ـ جامعة الزائة الزقازيق.
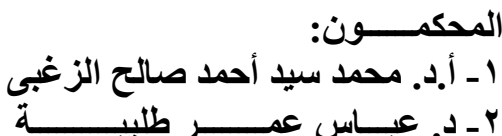